\title{
$\mathrm{HPLC} / \mathrm{UVD}$ 를 이용한 현미와 볏짚 중 MCPA의 잔류분석방법 확립
}

\author{
유기용 ${ }^{1}$, 강대원 $^{1}$, 최용화 $^{2}$, 한성수 $^{1 *}$
}

\section{Analytical Method for MCPA Residue in Brown Rice and Rice Straw by HPLC/UVD}

\author{
Ki-Yong Yoo ${ }^{1}$, Dae-Won Kang ${ }^{1}$, Yong-Hwa Choi ${ }^{2}$ and Seong-Soo Han ${ }^{1 *}$
}

ABSTRACT This study was carried out to establish the analytical method of MCPA residue in brown rice and rice straw by HPLC/UVD. When MCPA was extracted from sample under the $\mathrm{pH}$ 3.6 by adding acetone $200 \mathrm{~mL}$ and $1 \mathrm{~N}-\mathrm{HCl} 100 \mathrm{~mL}$, the extraction efficiency was high by $87 \%$. And purification efficiency was high by $83 \%$ when $5 \mathrm{~mL}$ of $1 \%$ methanol/acetonitrile was eluated by the florisil Sep-pak cartridge column. From spiking of $0.1 \mu \mathrm{g} \mathrm{mL} \mathrm{m}^{-1}$ and $0.25 \mu \mathrm{g} \mathrm{mL} \mathrm{L}^{-1}$ of MCPA to control sample, respectively, average recovery rate of MCPA in brown rice was $96.0 \%$ and $94.9 \%$ and that in rice straw was $92.5 \%$ and $88.2 \%$, respectively. Precision of experiment was very high by relative standard deviation of $1.5 \%$ to $5.7 \%$. In brown rice and rice straw treated with bentazone+MCPA $(11+1.2 \%)$ of $30 \mathrm{~kg}$ and $60 \mathrm{~kg}$ per ha at 30 days after rice transplanting, respectively, maximum residue limit was under $0.05 \mu \mathrm{gL}^{-1}$ of the recommended rate of Korean Food and Drug Administration. From the above results, the analytical procedure of MCPA in plants such as hydrolysis, saponification and derivatization were ommited, and retention time was faster and recovery rate was higher than the existed results of HPLC/UVD. Therefore, these results were greatly improved and seemed to be usefully applied for residue analysis of MCPA in plants.

Key words: analytical method; MCPA; brown rice and rice straw; HPLC/UVD.

\section{서 언}

Phenoxy acid계 제초제 MCPA[(4-Chloro-2-methylphenoxy) acetic acid]는 BASF에서 개발되어 1945년에 R. E. Slade에 의해 식물생장조절작용이 있음을 보고된 이 후, ICI사 Plant Protection Division(현재는 Syngenta

\footnotetext{
${ }^{1}$ 원광대학교 생명자원과학대학 식품· 환경학과, 570-749 전북 익산시 신용동 344-2(Department of Food and Environment Science, College of Life Science and Natural Resources, Wonkwang University, Iksan 570-749, Korea).

${ }^{2}$ 경북대학교 생태환경대학 생태환경시스템학부, 742-711 경북 상주시 가장동 386(School of Ecological \& Environmental System, College of Ecological \& Environmental Science, Kyungpook National University, Sangju 742-711, Korea).

* 연락저자(Corresponding author) Phone) +82-63-850-6678, Fax)+82-63-850-6678, E-mail) seshan@ wonkwang.ac.kr
} 
$\mathrm{AG}$ )에서 제초제로 도입되었으며, $\mathrm{MCPA}$ 는 1년생 및 다년생 광엽잡초의 생육기(post-emergence)처리 제초제로서 작용기작은 잎과 뿌리에 흡수 이행되는 선택성 이행형 호르몬형 제초제로 분열조직에 농축 되어 생육억제를 한다(Pesticide Manual 2006). 우리 나라에서는 2009년 한국잔디밭 일년생 및 다년생 잡 초방제를 위해 잡초생육초기 경엽처리제로 등록되어 사용되고 있고(한국작물보호협회 2009), 또한 논 잡 초방제를 위해 이앙 후 30 일 처리 제초제로 추후 등 록예정이어서 $\mathrm{MCPA}$ 의 사용면적과 사용량은 증가될 전망이다.

$\mathrm{MCPA}$ 의 제품분석방법으로는 infrared spectrometry 법(AOAC 1990; CIPAC 1985), HPLC법(CIPAC 1985; AOAC 1990), liquid/liquid chromatography (CIPAC 1985), 유도체의 GLC법(CIPAC 1985), 적 정법(CIPAC 1985) 등이 있다. Phenoxy계 제초제의 $\mathrm{GLC} / \mathrm{ECD}$ 에 의한 잔류분석방법으로는 Wolfgang과 Monika(1981)가 식물체 중 정량방법을 기술하였는 데, 그 방법은 알칼리 가수분해 후 산 추출, 혼합용매 분획, 겔침투크로마토그라피(GPC), 산/염기 분배, methylation 및 $\mathrm{GC} / \mathrm{MS}$ 정량으로 이루어져 있고, Gilsbach와 Thier(1982)는 밀가루 중 chlorophenoxy $\mathrm{acid}$ 와 그들 ester 일부의 검출과 정량법을 서술하고 있는데, 앞서 기술한 식물체 중 정량방법과 유사하였 다. 농약잔류분석법연구회(1995)와 유 등(2000)은 일 반적인 추출, 액액분배, 정제 이외의 과정에 추출 후 가수분해와 chloroethyl화제를 첨가한 유도체화의 과 정을 거쳐 잔류분석을 행하였다. 이와 같이 phenoxy 계 제초제의 $\mathrm{GLC} / \mathrm{ECD}$ 잔류분석법으로 허용된 절차 는 가수분해, 추출 및 esterification 또는 유도체화를 포함하고 있는데, 이 방법들은 시료조제 절차의 복잡 성으로 인한 시약의 낭비, 시간과 인력의 소모성 그리 고 유기용매 취급으로 인한 위해성이라는 단점을 가 지고 있다.

Stevens와 Ground(1979)는 HPLC에 의한 MCPA 분 석법을 연구하기 시작하였고, Ground와 Stevens(1980) 는 $\mathrm{MCPA}$ 의 ester와 salt의 $\mathrm{HPLC}$ 방법을 $\mathrm{AOAC}$ 법 (1990)에 따라 모든 시료에 내표준용액-saponification 용액을 첨가하여 분석하였으며, Hamann과 Kettrup
(1987)은 물 시료에 spiking한 phenoxy acid계 제초 제의 미량분석을 위한 HPLC 분석법으로 액-액추출 에 이어 on-line enrichment, 고상농축, 밸브교환 시 스템으로 enrichment column에서 용출하였는바, $\mathrm{pH}$ 2.0 에서 추출율이 높고 분석효율도 높으며 재현성도 있다고 하였다. Hamann 등(1989)은 phenoxy acid계 제초제의 HPLC 분석을 위해 몇 가지 고정상과 이동 상을 사용하여 평가하였고, on-line 운영을 위한 enrichment phase column 교환을 통하여 시험한 결 과, 고정상 가운데 octadecyl silica와 aminopropyl silica가 적합한 것으로 밝혔고, 정량분석에는 여러 가 지 mobile phase가 가능하다고 확인하였으며, 위 두 상에서 on-line mode에 연결될 수 있는enrichment phase와의 조합 가능성을 찾아냈다. Hoke 등(1986) 은 HPLC를 사용하여 물 중 phenoxy acid계 제초제 의 정량절차를 기술한 바, 회수율은 다소 낮지만 존재 유무를 파악하고, Meier 등(1989)은 HPLC/UV에 on-line enrichment를 사용하여 토양 중 MCPA의 회 수율을 분석한 바, 회수율은 $72-89 \%$ 로 낮은 편이었 고, CIPAC(1985)에서 서술한 바에 따르면 시료를 내 표준용액에 녹이고 역상컬럼상에서 HPLC로 정량하 였을 때 retention time은 16.3 분이었다.

최근 분석기기들의 발전으로 비용을 적게, 분석시 간을 빠르게 분석하는데 적합하며 높은 감도와 우수 한 재현성을 보여주고 있어 분석방법의 새로운 개발 이 필요한 실정이다. 따라서 본 연구에서는 식물체인 현미와 볏짚 중 $\mathrm{HPLC} / \mathrm{UVD}$ 에 의한 $\mathrm{MCPA}$ 의 잔류 분석방법을 새롭게 확립하여 기존의 $\mathrm{GC} / \mathrm{ECD}$ 나 $\mathrm{HPLC}$ 에 의한 방법들의 단점을 보완하고자 하였고, 잔류농약의 안전성 평가를 위한 분석방법으로 활용 하는 데 기여하고자 하였다.

\section{재료 및 방법}

\section{기기 및 장치}

잔류농약 분석에 사용한 HPLC/UVD는 Futecs (Korea)사의 제품으로 detector는 UV/VIS detector NS2100D, pump는 dual piston pump NS2004GP, 
column oven은 AT3000을 사용하였고, column은

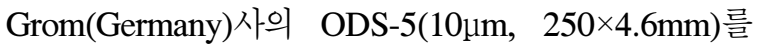
사용하였다. 또한 시료의 농축에는 Büchi(Switzerland) 사의 rotary vacuum evaporator R-114가 사용되었 고, vacuum system은 EYELA(Japan)사의 aspirator SB-651을 사용하였다. Mobile phase 여과시 Millipore (USA)사의 감압 여과장치와 Whatman(UK)사의 membrane filter $(0.45 \mu \mathrm{m} \times 47 \mathrm{~mm})$ 를 사용하였으며, 시 료 정제시 Sep-pak cartridge를 사용하기 위하여 Supelco(USA)사의 vacuum manifold를 사용하였다. 이외에 시료 조제는 동아산업(Korea) 현미겸용정미 기 DA-888을 이용하여 도정하였고, 마쇄는 Jisico (Korea)의 J-NCM cutting mill을 사용하였다.

\section{표준품 및 시약}

MCPA 표준품(순도 99.9\%)은 동부하이텍(주)으로 부터 분양받아 사용하였고(그림 1), 잔류농약 분석에 서 사용한 시약 중 acetone과 dichloromethane은 J. T. Baker(USA)사의 residue analysis grade, sodium sulfate anhydrous는 Showa(Japan)사의 10 60 mesh, celite는 Fluka(Japan)사의 Hyflo Super Cel ${ }^{\circledR}$ 을 사용하 였고, 시료의 정제는 Waters(USA)사의 florisil $(6 \mathrm{~mL}$, $1 \mathrm{~g}$ ), silica(3mL, 1g), $\mathrm{C}_{18}(1 \mathrm{~mL}, 100 \mathrm{mg}), \mathrm{NH}_{2}$-propyl $(6 \mathrm{~mL}, 1 \mathrm{~g})$ Sep-pak ${ }^{\circledR}$ cartridge column을 사용하였 다. $\mathrm{HPLC} / \mathrm{UVD}$ 의 이동상 조제와 정용을 위한 acetonitrile, water, n-Hexane은 J. T. Baker(USA)사 의 HPLC grade를 사용하였다.

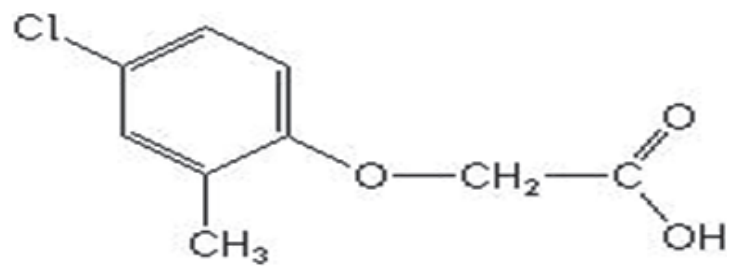

Fig. 1. Chemical structure of MCPA.

\section{벼 재배 및 시료채취}

본 실험에서 사용한 식물체 재료는 2008년 5 10 월, 전북 익산시 원광대학교 시험구에서 재배한 벼를 사용하였다. 품종은 신동진 이었으며, $30 \times 14 \mathrm{~cm}$ 의 재
식밀도로 5 월 19 일 어린모 기계이앙하여 일반관행으 로 재배하였고, Bentazone+MCPA(11+1.2\%) 합제를 이앙 후 30 일에 ha당 $30 \mathrm{~kg}$ (기준량)과 $60 \mathrm{~kg}$ (배량)을 각각 처리하였으며, 10 월 19 일에 수확하였다. 수확한 시료는 풍건 후 벼와 볏짚으로 분리하여 현미시료는 정미기를 이용하여 왕겨를 벗겨낸 후 cutting mill로 마쇄 후 $40 \mathrm{mesh}$ 체를 통과시켜 사용하였으며, 볏짚 은 $2 \mathrm{~cm}$ 크기로 절단하여 cutting mill로 마쇄 후 40 mesh 체를 통과시켜 사용하였다. 두 시료 모두 mason jar에 담아 $-20^{\circ} \mathrm{C}$ deep freezer에 보관하면서 잔류분 석에 사용하였다.

\section{HPLC/UVD 기기 운용조건}

$\mathrm{MCPA}$ 잔류분석에서 $\mathrm{HPLC} / \mathrm{UVD}$ 의 운용조건은 표 1 과 같은 바, 사용되어진 column은 Grom(Germany)사 의 $250 \times 4.6 \mathrm{~mm}, 5 \mu \mathrm{m}$ Grom-sil 120 ODS-5 ST를 사용 하였으며, column oven의 온도는 $40^{\circ} \mathrm{C}$ 를 유지시켜 주었다. Mobile phase는 acetonitrile과 water를 85 : $15(\mathrm{v} / \mathrm{v})$ 의 비율로 혼합하여 여과장치를 통과시킨 후 탈기하여 사용하였으며, flow rate는 분당 $0.5 \mathrm{~mL}$, injection volume은 $20 \mu \mathrm{L}$ 로 하였다.

Table 1. Operation condition of HPLC/UVD for MCPA residue analysis.

\begin{tabular}{|c|c|c|}
\hline \multirow{4}{*}{ Column } & Type & GROM-SIL 120 ODS-5 \\
\hline & Length & $25 \mathrm{~mm}$ \\
\hline & Diameter & $4.6 \mathrm{~mm}$ \\
\hline & Particle size & $5 \mu \mathrm{m}$ at $30^{\circ} \mathrm{C}$ \\
\hline \multirow{2}{*}{ Mobile phase } & Solvent & acetonitrile : water $(85: 15, \mathrm{v} / \mathrm{v})$ \\
\hline & Flow rate & $0.5 \mathrm{~mL} \mathrm{~min}^{-1}$ \\
\hline Column oven & Temp. & $40^{\circ} \mathrm{C}$ \\
\hline Wave length & & $250 \mathrm{~nm}$ \\
\hline Injection vol. & & $20 \mu \mathrm{L}$ \\
\hline
\end{tabular}

\section{표준용액 및 표준검량선 작성}

MCPA 표준품(purity $99.9 \%) 100.1 \mathrm{mg}$ 을 $1 \mathrm{~L}$ 의 acetonitrile에 녹여 $100 \mu \mathrm{g} \mathrm{mL}^{-1}$ 의 표준용액을 조제하 였고, working solution은 이 표준용액을 acetonitrile 로 희석하여 $0.5,1.0,2.0,4.0$ 및 $10.0 \mathrm{\mu g} \mathrm{mL} \mathrm{gL}^{-1}$ 로 만들 
고 이 중 $20 \mu \mathrm{L}$ 를 $\mathrm{HPLC} / \mathrm{UVD}$ 에 주입하여 얻어진 chromatogram상의 peak height를 기준으로 표준검 량선을 작성하였다.

\section{용매별 추출효율}

용매별 추출효율을 확인하기 위하여 현미와 볏짚 시료 $40 \mathrm{~g}$ 에 $\mathrm{MCPA}$ 표준용액을 각각 $2 \mu \mathrm{g} \mathrm{mL}^{-1}$ 이 되 도록 spiking 후 acetone, acetonitrile, n-Hexane, dichloromethane을 각각 $200 \mathrm{~mL}$ 씩 넣은 다음 $1 \mathrm{~N}-\mathrm{HCl}$ 을 $100 \mathrm{~mL}$ 씩 첨가하여 30 분간 진탕추출 하였으며, 추 출시 $\mathrm{pH}$ 는 3.6이었다. 이 추출액은 감압여과하여 농 축한 다음 acetonitrile $1 \mathrm{~mL}$ 로 정용하여 그 중 $20 \mu \mathrm{L}$ 를 HPLC/UVD에 주입하여 분석하였다.

\section{충진제별 정제효율}

충진제별 컬럼은 florisil $(6 \mathrm{~mL}, 1 \mathrm{~g})$, silica $(3 \mathrm{~mL}$, $1 \mathrm{mg}), \mathrm{C}_{18}(1 \mathrm{~mL}, 100 \mathrm{mg}), \mathrm{NH}_{2}$-propyl(6mL, 1g) Sep$\mathrm{pak}^{\circledR}$ cartridge column을 사용하였고, 각 column은 $\mathrm{n}$-Hexane $10 \mathrm{~mL}$ 로 conditioning을 하였다. 앞서 수행 한 실험결과에서 추출효율이 가장 좋았던 acetone $200 \mathrm{~mL}+1 \mathrm{~N}-\mathrm{HCl} 100 \mathrm{~mL}$ 로 추출하여 농축한 추출시 료를 각 컬럼에 loading 후 $\mathrm{n}$-Hexane $10 \mathrm{~mL}$ 로 세척 하여 $1 \%$ methanol/acetonitrile $5 \mathrm{~mL}$ 로 용출하였고 농축하여 acetonitrile $1 \mathrm{~mL}$ 로 최종 정용하였다. 그 중 $20 \mu \mathrm{L}$ 를 HPLC/UVD에 주입하여 분석하였다.

\section{회수율, 검출한계 및 정밀도}

현미, 볏짚시료 $40 \mathrm{~g}$ 에 각각 $0.1 \mu \mathrm{g} \mathrm{mL}^{-1}, 0.25 \mathrm{\mu g}$ $\mathrm{mL}^{-1}$ 의 농도가 되도록 $\mathrm{MCPA}$ 표준용액을 각각 spiking한 후 앞서 서술한 추출 및 정제과정을 수행하 여 HPLC 분석으로 얻어진 chromatogram의 peak height를 근거로 표준검량선에 의해 양을 산출한 다 음 회수율과 검출한계를 구하였다. 또한, 실험의 정밀 도를 평가하기 위해서 회수율 실험과 마찬가지로 현 미와 볏짚 시료에 각각 0.1 과 $0.25 \mu \mathrm{g} \mathrm{mL}^{-1}$ 이 되도록 $\mathrm{MCPA}$ 표준용액을 spiking하여 상기와 같은 실험방 법을 거쳐 나온 값의 상대표준편차(RSD)를 계산하였 고, 그 결과를 바탕으로 정밀도를 나타내었다. 모든 실험은 3 반복으로 수행하였다.

\section{현미와 볏짚 중 잔류량 분석}

현미와 볏짚 시료 각각 $40 \mathrm{~g}$ 씩을 $500 \mathrm{~mL}$ 삼각플라 스크에 취하여 회수율 분석과 같은 방법으로 전처리 하였으며, acetonitrile $1 \mathrm{~mL}$ 로 최종 정용한 용액 중 $20 \mu \mathrm{L}$ 를 HPLC/UVD에 주입하여 분석하였다.

\section{결과 및 고찰}

\section{표준검량선}

MCPA 표준품을 acetonitrile로 용해시켜 $0.1 \sim 2.0$ $\mu \mathrm{g} \mathrm{mL}^{-1}$ 농도로 희석하여 HPLC/UVD에 주입 후 얻 어진 chromatogram상의 peak height로 표준검량선 을 작성하였다. 그 결과 검량선의 직선 회귀식은 $\mathrm{y}=518.16 \mathrm{x}+506.55$ 이었으며, 검량선 작성을 위한 농 도범위에서 결정계수 $\left(\mathrm{R}^{2}\right)$ 가 0.9972로 직선형을 보여 농도와 peak height간 높은 정의 상관관계를 나타내었 다(그림 2). 표준검량선 작성시 사용한 chromatogram 을 그림 3에 나타내었고, 본 기기운용조건에서 $\mathrm{MCPA}$ 표준품의 Retention time(Rt)은 6.5분이었다. 이 결과 는 모든 시료를 내표준물질 salicylic acid로 녹여 역 상컬럼상에서 $\mathrm{HPLC}$ 로 분석한 Rt 16.3분(CIPAC 1985)에 비하면 2.5 배 이상 빠른 시간에 분리됨으로 써 분석시간을 크게 단축할 수 있어 시간소모성의 단 점을 개선한 좋은 결과이다.

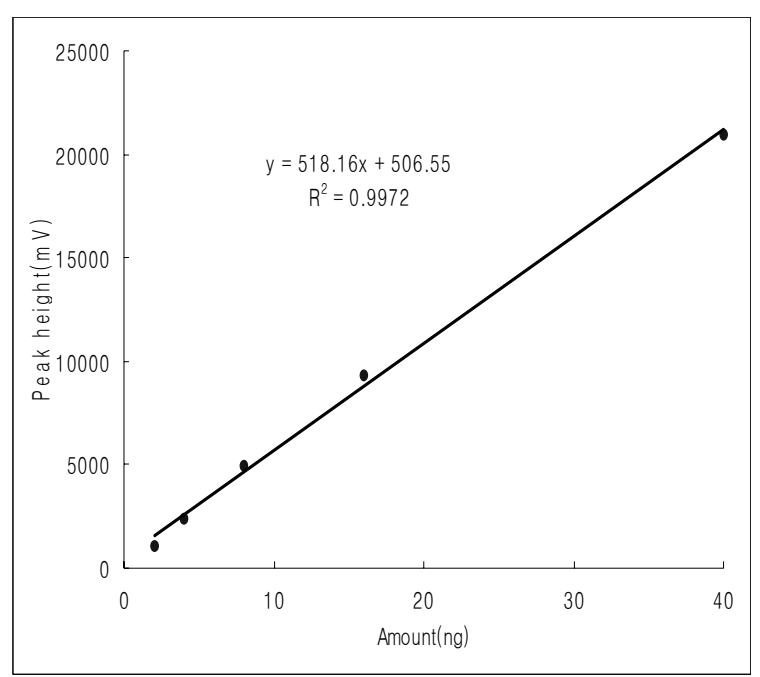

Fig. 2. Standard calibration curve of MCPA. 


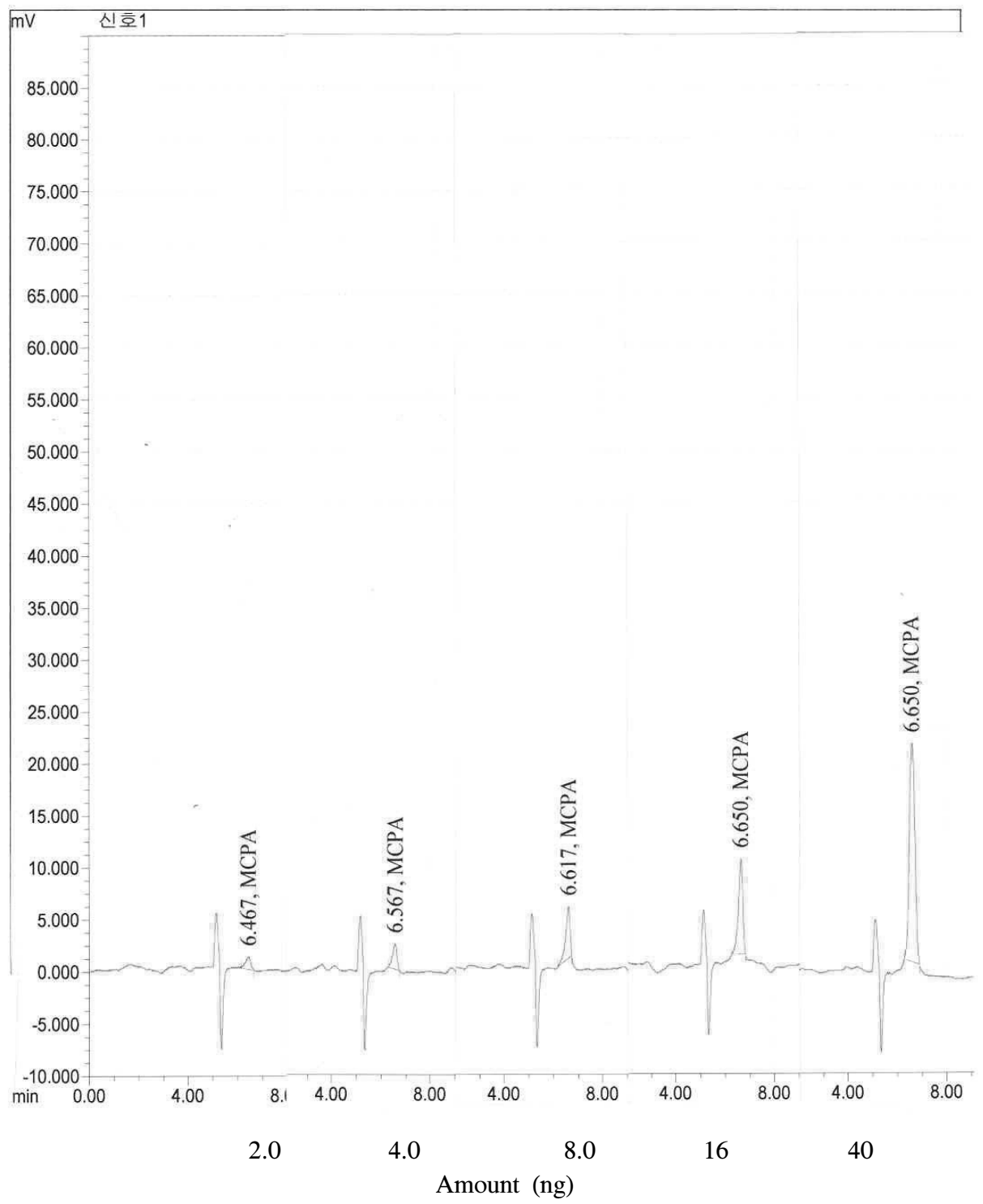

Fig. 3. HPLC/UVD chromatograms of MCPA standard.

Table 2. Extraction efficiency by the different solvents.

\begin{tabular}{ccc}
\hline \multirow{2}{*}{ Solvents } & \multicolumn{2}{c}{ Extraction efficiency $(\%)^{1)}$} \\
\cline { 2 - 3 } & With $1 \mathrm{~N}-\mathrm{HCl}$ & Without $1 \mathrm{~N}-\mathrm{HCl}$ \\
\hline Acetone & 87 & 61 \\
Acetonitrile & 18 & 25 \\
n-Hexane & 0 & 0 \\
Dicloromethane & 0 & 0 \\
\hline
\end{tabular}

${ }^{1)}$ Results were based on 3 replicates.

\section{용매별 추출효율}

현미와 볏짚 시료 $20 \mathrm{~g}$ 에 각각 $\mathrm{MCPA}$ 표준용액이 2 $\mu \mathrm{g} \mathrm{mL}^{-1}$ 이 되도록 spiking하여 acetone, acetonitrile, $\mathrm{n}$-Hexane, dichloromethane 각각의 용매 $200 \mathrm{~mL}$ 에 $1 \mathrm{~N}-\mathrm{HCl} 100 \mathrm{~mL}$ 를 각각 첨가한 것과 첨가하지 않고 추출한 용매별 추출효율을 확인한 결과, $1 \mathrm{~N}-\mathrm{HCl}$ 을 첨가하고 acetone 추출한 시료에서 $87 \%$, acetonitrile $100 \mathrm{~mL} 18 \%$ 의 효율을 나타내었고, $1 \mathrm{~N} \mathrm{HCl}$ 을 첨가 하지 않고 acetone으로만 추출한 시료에서는 $61 \%$, acetonitrile로 추출한 시료에서는 $25 \%$ 이었다. n- 
Hexane과 dichloromethane에 각각 $1 \mathrm{~N}-\mathrm{HCl}$ 을 첨가 하거나 첨가하지 않고 추출한 시료에서는 추출이 되 지 않았다. 이 결과를 바탕으로 MCPA는 acetone $200 \mathrm{~mL}$ 와 $1 \mathrm{~N}-\mathrm{HCl} 100 \mathrm{~mL}$ 을 첨가하여 추출하였을 때, 즉 산성조건(pH 3.6)에서 acetone으로 추출했을 때 가장 추출이 잘 되는 것으로 나타났다..

\section{충진제별 정제효율}

위에서 추출한 방법으로 acetone과 $1 \mathrm{~N}-\mathrm{HCl}$ 첨가 후 추출한 추출액을 농축하여 충진제별로 정제한 결과,

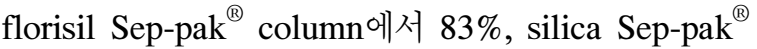
column에서 $12 \%$ 를 나타내었고, $\mathrm{C}_{18}$ 및 $\mathrm{NH}_{2}$-propyl Sep-pak ${ }^{\circledR}$ column에서는 확인되지 않아 florisil column 에서 $\mathrm{MCPA}$ 에 대한 정제 효율이 가장 높은 것으로 확 인되었다(표 3).

Table 3. Cleanup efficiency by packing materials of prepacked sep-pak column.

\begin{tabular}{cc}
\hline Packing materials & Purification efficiency $(\%)^{1)}$ \\
\hline Florisil & 83 \\
Silica & 12 \\
$\mathrm{C}_{18}$ & 0 \\
$\mathrm{NH}_{2}$-propyl & 0 \\
\hline
\end{tabular}

${ }^{1)}$ Results were based on 3 replicates.

\section{분석방법의 확립}

위와 같은 실험결과들을 바탕으로 현미와 볏짚시 료 중 $\mathrm{HPLC}$ 에 의한 $\mathrm{MCPA}$ 잔류분석방법을 확립하 여 그림 4에 요약 - 정리하였다. 즉, 현미 중 $\mathrm{MCPA}$ 의 분석방법은 acetone $200 \mathrm{~mL}$ 과 $1 \mathrm{~N}-\mathrm{HCl} 100 \mathrm{~mL}$ 을 가하여 30 분간 진탕추출하고, 이 추출액을 celite를 통과시켜 감압여과하였으며, acetone $50 \mathrm{~mL}$ 로 잔사 를 씻어 앞의 여과액과 합하여 감압농축하였다. 농축 한 수용액은 $5 \% \mathrm{NaCl} 50 \mathrm{~mL}$ 을 가하여 분액여두로 옮기고 $\mathrm{n}$-Hexane $100 \mathrm{~mL}$ 와 $50 \mathrm{~mL}$ 로 2 회 전용한 $\mathrm{n}$-Hexane 추출액을 sodium sulfate anhydrous를 이 용하여 탈수여과한 후 감압농축시켰다. 농축한 시료 를 다시 $\mathrm{n}$-Hexane $30 \mathrm{~mL}$ 로 용해하여 분액여두로 옮 기고 헥산포화아세토나이트릴 $30 \mathrm{~mL}$ 씩 2 회 분배하여 감압농축하였다. 건고된 시료는 n-Hexane $5 \mathrm{~mL}$ 용해 하여 $\mathrm{n}$-Hexane $10 \mathrm{~mL}$ 로 활성화시킨 florisil cartridge column $(6 \mathrm{~mL}, 1 \mathrm{~g})$ 에 loading 하여 $\mathrm{n}$-Hexane $10 \mathrm{~mL}$ 로 세척 후 acetonitrile $5 \mathrm{~mL}$ 로 용출하여 농축 건고하고, acetonitrile $2 \mathrm{~mL}$ 로 최종 정용하여 그 중 $20 \mu \mathrm{L}$ 를 $\mathrm{HPLC} / \mathrm{UVD}$ 에 주입하여 분석하였다.

볏짚의 경우는 acetone $200 \mathrm{~mL}$ 과 $1 \mathrm{~N}-\mathrm{HCl} 100 \mathrm{~mL}$ 을 30 분간 진탕추출하고, 이 추출액을 celite를 통과시켜 감압 여과한 다음 acetone $50 \mathrm{~mL}$ 로 잔사를 씻어 앞의

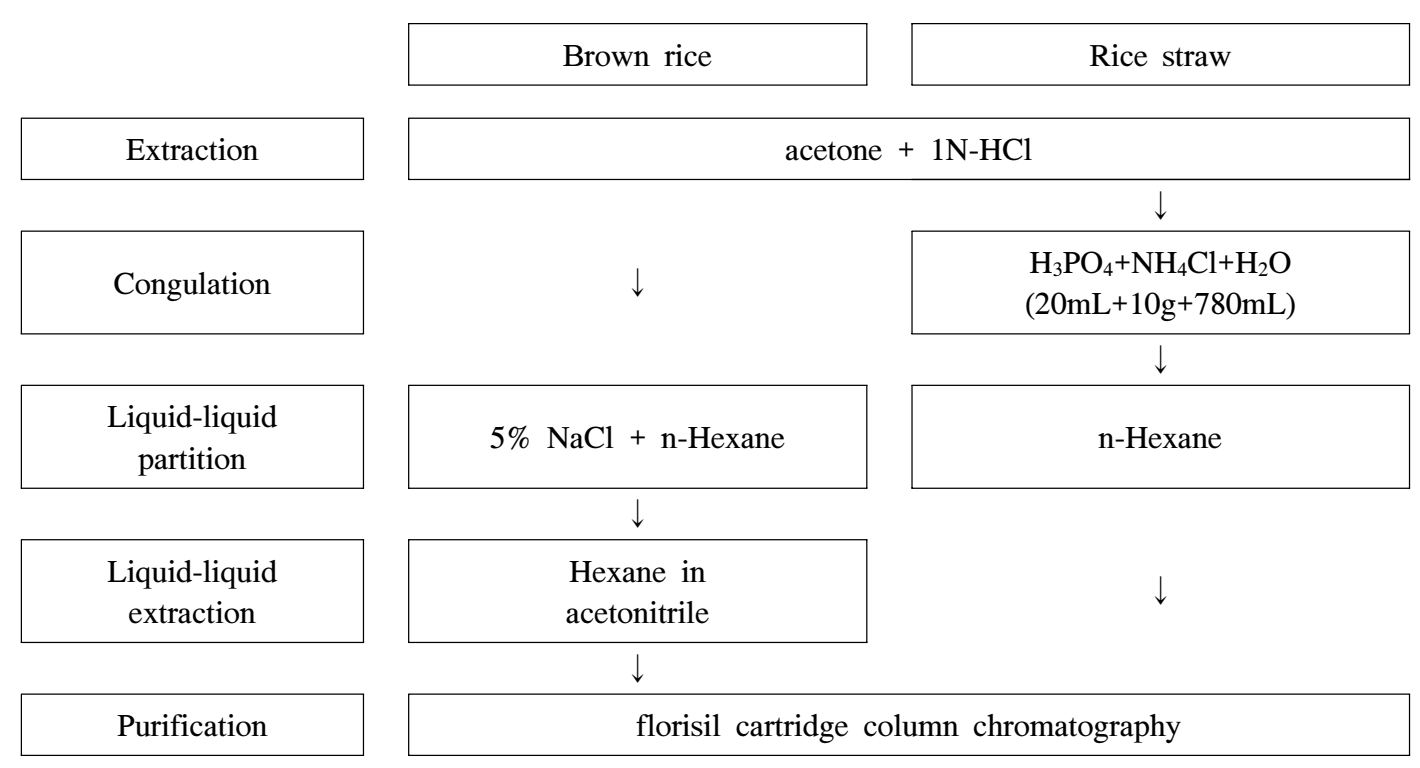

Fig. 4. Scheme of extraction and purification procedures of MCPA in brown rice and rice straw. 
Table 4. Recoveries of MCPA in brown rice and rice straw.

\begin{tabular}{|c|c|c|c|c|c|c|}
\hline \multirow[b]{2}{*}{ Classification } & \multirow{2}{*}{$\begin{array}{c}\text { Spiked } \\
\left(\mu \mathrm{g} \mathrm{mL} L^{-1}\right)\end{array}$} & \multicolumn{3}{|c|}{ Recovery(\%) } & \multirow{2}{*}{$\begin{array}{c}\mathrm{LOD}^{1)} \\
\left(\mu \mathrm{g} \mathrm{mL}{ }^{-1}\right)\end{array}$} & \multirow{2}{*}{$\begin{array}{c}\mathrm{MDA}^{2)} \\
(\mathrm{ng})\end{array}$} \\
\hline & & $\begin{array}{c}\text { Replication } \\
1\end{array}$ & $\begin{array}{c}\text { Replication } \\
2\end{array}$ & $\begin{array}{c}\text { Replication } \\
3\end{array}$ & & \\
\hline \multirow{2}{*}{$\begin{array}{l}\text { Brown } \\
\text { rice }\end{array}$} & 0.1 & 96.0 & 94.7 & 97.4 & \multirow{2}{*}{$0.005^{3)}$} & \multirow{2}{*}{2.0} \\
\hline & 0.25 & 97.3 & 95.7 & 91.8 & & \\
\hline \multirow{2}{*}{$\begin{array}{l}\text { Rice } \\
\text { straw }\end{array}$} & 0.1 & 95.3 & 95.8 & 86.4 & \multirow{2}{*}{0.005} & \multirow{2}{*}{2.0} \\
\hline & 0.25 & 83.5 & 92.3 & 88.7 & & \\
\hline
\end{tabular}

${ }^{1)}$ Limit of detection.

${ }^{2)}$ Minimum detectable amount.

3) $2.0 n g \times \frac{2 m L}{20 \mu L} \times \frac{1}{40 g}=0.005 \mu g m L^{-1}$.

여과액과 합하여 감압농축하였다. 농축된 수용액에 acetone $10 \mathrm{~mL}$, 응고촉진제 $\left[\mathrm{H}_{3} \mathrm{PO}_{4}+\mathrm{NH}_{4} \mathrm{Cl}+\mathrm{H}_{2} \mathrm{O}\right.$ $(20 \mathrm{~mL}+10 \mathrm{~g}+780 \mathrm{~mL})] 40 \mathrm{~mL}$ 를 가하여 30 분간 방치 한 후 celite를 이용, 감압여과하고 이를 $300 \mathrm{~mL}$ 분액

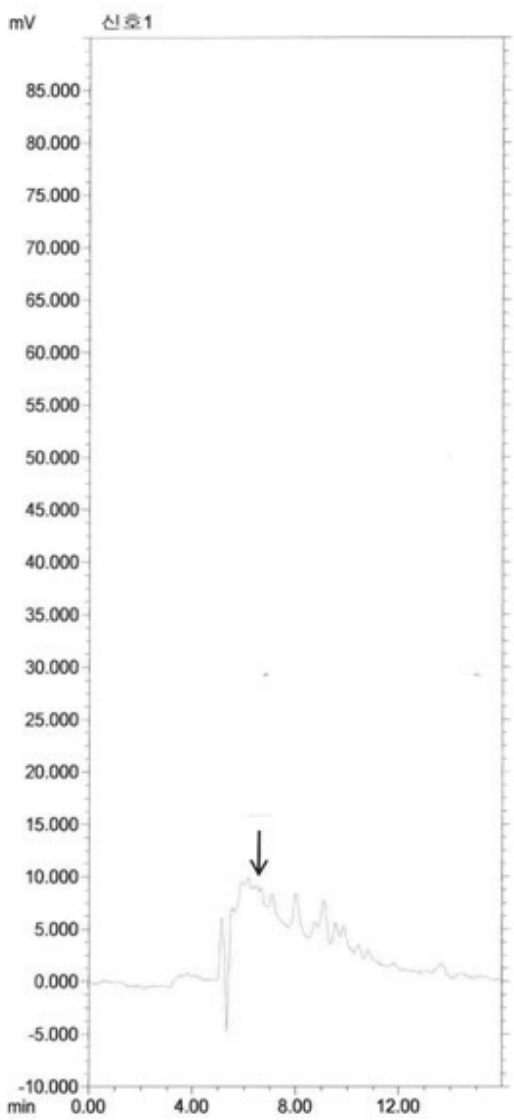

여두로 옮겨 $\mathrm{n}$-Hexane $50 \mathrm{~mL}$ 로 2 회 분배추출한 후 sodium sulfate anhydrous를 통과시켜 탈수여과하였 다. 이후의 분석절차는 현미에서 기술한 절차와 동일 하게 수행하였다.

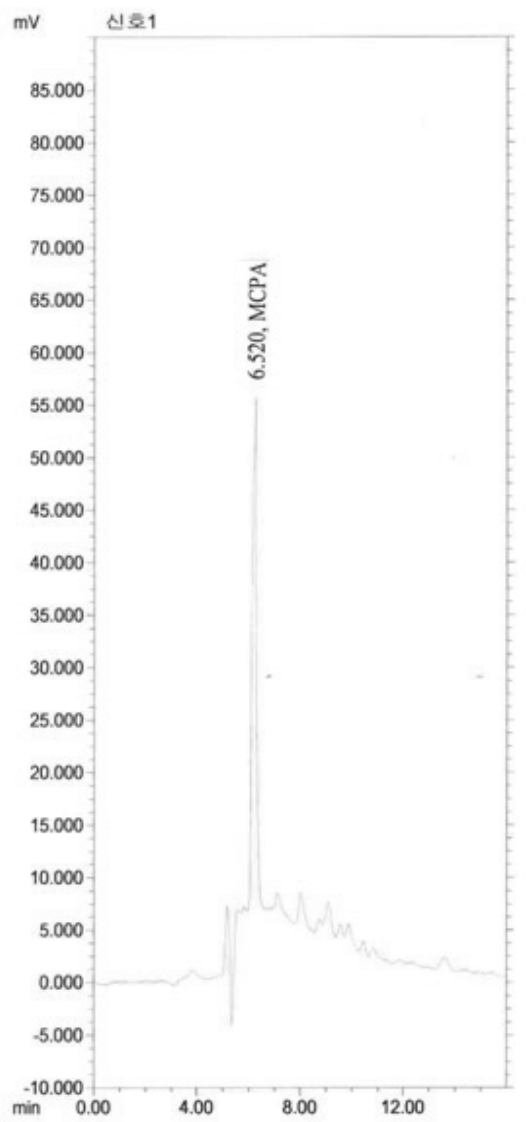

Fig. 5. HPLC/UVD chromatograms of control (left) and spiked MCPA (right) in brown rice. 

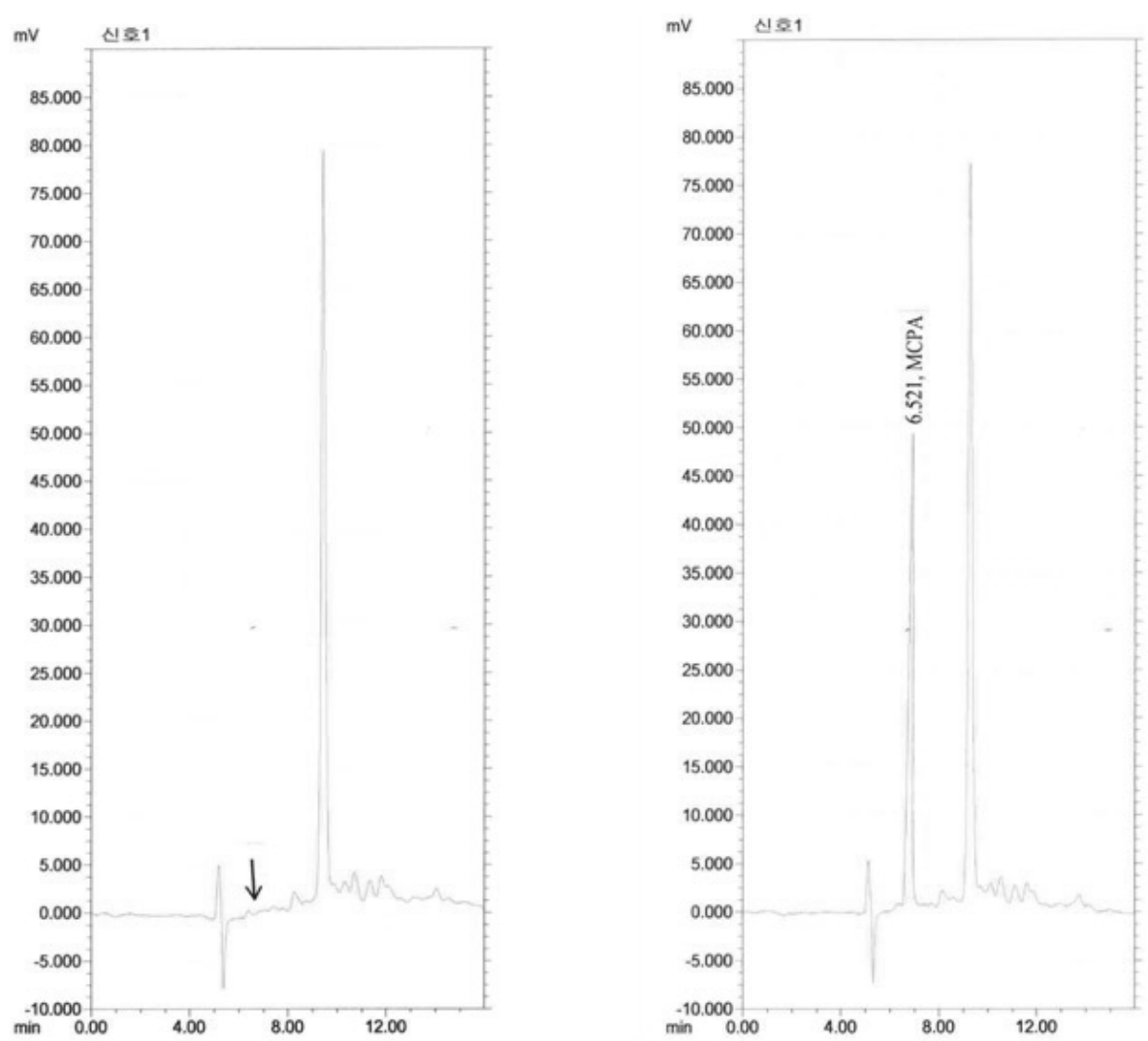

Fig. 6. HPLC/UVD chromatograms of control (left) and spiked MCPA (right) in rice straw.

\section{회수율, 검출한계 및 정밀도}

분석법상의 최소검출량(MDA)과 검출한계(LOD) 는 각각 $2.0 \mathrm{ng}$ 과 $0.005 \mu \mathrm{g} \mathrm{mL} \mathrm{m}^{-1}$ 이었으며, 그 결과를 표 4에 나타내었다.

현미 무처리 시료에 $0.1 \mu \mathrm{g} \mathrm{mL}^{-1}$ 과 $0.25 \mu \mathrm{g} \mathrm{mL}^{-1}$ 이 되도록 spiking하여 분석한 평균 회수율은 각각 $96.0 \%$ 와 $94.9 \%$ 이었으며, 볏짚의 경우 평균 회수율 은 각각 $92.5 \%$ 와 $88.2 \%$ 를 나타냈다. 이 결과는 Maier 등(1989)이 토양 중 MCPA의 잔류량을 분석 한 결과인 72 89\% 보다 높았다. 현미와 볏짚 두 시 료의 무처리와 회수율시험 chromatogram은 그림 5 와 6 에 나타내었다.

실험의 정밀도를 확인한 결과, 현미 $0.1 \mu \mathrm{g} \mathrm{mL}^{-1}$ 과

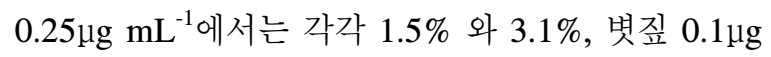
$\mathrm{mL}^{-1}$ 과 $0.25 \mu \mathrm{g} \mathrm{mL}^{-1}$ 에서는 각각 $5.7 \%$ 와 $5.0 \%$ 로써 두 시료에서 모두 $10 \%$ 이내의 높은 정밀도를 나타내 었다(표 5).
Table 5. Precision of analytical method of MCPA in brown rice and rice straw.

\begin{tabular}{ccc}
\hline \multirow{2}{*}{$\begin{array}{c}\text { Spiked } \\
\text { concentration } \\
\left(\mu \mathrm{g} \mathrm{mL}^{-1}\right)\end{array}$} & brown rice & rice straw \\
\cline { 2 - 3 } 0.1 & $1.5 \pm 0.2^{1)}$ & $5.7 \pm 0.4$ \\
\hline 0.25 & $3.1 \pm 0.3$ & $5.0 \pm 0.3$ \\
\hline
\end{tabular}

1) mean $\pm \mathrm{SD}$.

\section{현미와 볏짚 중 잔류량 분석}

Bentazone+MCPA $(11+1.2 \%)$ 합제를 기준량 $(30 \mathrm{~kg}$ $\left.\mathrm{ha}^{-1}\right)$ 과 배량 $\left(60 \mathrm{~kg} \mathrm{ha}^{-1}\right)$ 으로 처리하여 재배한 현미와 볏짚 시료의 잔류량을 분석한 결과 현미와 볏짚 두 시료 모두 식품의약품안전청(2009)이 권고한 잔류허 용량 $0.05 \mu \mathrm{gL}^{-1}$ 미만으로 확인되었다(표 6). 
Table 6. Residue amount of MCPA in brown rice and rice straw.

\begin{tabular}{|c|c|c|c|c|c|c|}
\hline \multirow{2}{*}{ Classification } & \multirow{2}{*}{ Treatment } & \multicolumn{4}{|c|}{ Residue amount of MCPA $\left(\mu \mathrm{g} \mathrm{mL}^{-1}\right)$} & \multirow{2}{*}{$\begin{array}{c}\mathrm{MRL}^{1)} \\
\left(\mu \mathrm{gL}^{-1}\right)\end{array}$} \\
\hline & & Rep. 1 & Rep. 2 & Rep. 3 & Average & \\
\hline \multirow{3}{*}{$\begin{array}{l}\text { Brown } \\
\text { rice }\end{array}$} & Untreated & $<0.005$ & $<0.005$ & $<0.005$ & $<0.005$ & \multirow{3}{*}{$\begin{array}{c}0.05 \\
\text { KFDA }^{2)}\end{array}$} \\
\hline & 1 & $<0.005$ & $<0.005$ & $<0.005$ & $<0.005$ & \\
\hline & 2 & $<0.005$ & $<0.005$ & $<0.005$ & $<0.005$ & \\
\hline \multirow{3}{*}{$\begin{array}{l}\text { Rice } \\
\text { straw }\end{array}$} & Untreated & $<0.005$ & $<0.005$ & $<0.005$ & $<0.005$ & \multirow{3}{*}{-} \\
\hline & 1 & $<0.005$ & $<0.005$ & $<0.005$ & $<0.005$ & \\
\hline & 2 & $<0.005$ & $<0.005$ & $<0.005$ & $<0.005$ & \\
\hline
\end{tabular}

1) Maximum residue limit.

${ }^{2)}$ Korean Food and Drug Administration.

\section{요 약}

$\mathrm{HPLC} / \mathrm{UVD}$ 를 이용한 현미와 볏짚 중 $\mathrm{MCPA}$ 의 잔류분석방법 확립하고자 용매별 추출효율과 충진 제별 정제효율을 검토한 결과, 용매별 추출효율은 시료 $20 \mathrm{~g}$ 에 acetone $200 \mathrm{~mL}$ 와 $1 \mathrm{~N}-\mathrm{HCl} 100 \mathrm{~mL}$ 의 혼 합용매(pH 3.6)를 사용하는 것이 $87 \%$ 로 높은 효율 을 보였고, 충진제별 정제효율은 florisil $(6 \mathrm{~mL}, 1 \mathrm{~g})$ Sep-pak ${ }^{\circledR}$ cartridge column에서 1\% methanol/ acetonitile 용출이 $83 \%$ 의 효율을 나타내었다. 이 결 과를 토대로 현미와 볏짚 시료 중의 MCPA 잔류분석 을 수행하였는바, 평균회수율은 현미의 경우 $96.0 \%$ 와 $94.9 \%$ 이었으며, 볏짚의 경우 $92.5 \%$ 와 $88.2 \%$ 로 높은 회수율이었고, 실험의 정밀도는 상대표준편차 $1.5 \sim 5.7 \%$ 로 매우 높았다. 벼 이앙 후 30 일에 bentazone+MCPA $(11+1.2 \%)$ 합제를 ha당 $30 \mathrm{~kg}$ 과 $60 \mathrm{~kg}$ 을 각각 처리하여 재배한 현미와 볏짚 중 $\mathrm{MCPA}$ 잔류량은 모든 처리에서 식품의약품안전청이 권고한 잔류허용량인 $5 \mu \mathrm{g} \mathrm{mL}^{-1}$ 미만이었다. $\mathrm{MCPA}$ 의 HPLC 분석조건과 잔류분석절차의 결과는 가수분 해, 유도체화, saponification과 같은 복잡한 분석절차 를 생략할 수 있고, Rt가 기존 $16.5 \mathrm{~min}$.에서 6.5 $\min$.으로 빨라져 인체위해성과 시간소모성의 단점을 개선하였으며, 회수율을 높이고 정밀도가 높은 결과 로써 현미와 볏짚 중 $\mathrm{HPLC}$ 에 의한 MCPA 잔류분석 에 유용하게 적용할 수 있을 것으로 판단된다.

\section{감사의 글}

이 논문은 2010년도 원광대학교의 교비 지원에 의 하여 수행되었으며, 이에 감사드립니다.

\section{인 용 문 헌}

식품의약품안전청. 2009. 식품의 농약잔류허용기준. p. 122.

유홍일, 이해근, 전성환. 2000. 농약잔류분석방법. p. 208-209.

한국작물보호협회. 2008. 농약사용지침서. p. 879.

農藥殘留分析法研究班. 1995. 農藥の 殘留分析法. p. 396-398.

Association of Official Analytical Chemists (AOAC). 1990. Official Methods of Analysis. 15th Ed. p. 187.

British Crop Protection Council. 2006. Pesticide manual 14th edition. pp. 653-655.

Collaborative International Pesticides Analytical Council (CIPAC). 1985. CIPAC Handbook 1C. pp. 2137-2145.

Gilsbach W. und H. P. Thier. 1982. Beiträge zur rückstandsanalyse von chlorphnoxycarbonsäureherbiciden in weizenmehl. Z. Lebensm Unters 
Forsch 175:327-332.

Ground, R. B., and T. S. Stevens. 1980. Isomer specific assay of ester and salt formulations of 2-methyl-4-chlorphenoxyacetic acid and 2,4,5trichlorophenoxy-acetic acid by high pressure liquid chromatography : collaborative study. J. Assoc. Off. Anal. Chem. 63(4):873-878.

Hamann, R., and A. Kettrup. 1987. Determination of phenoxy acid herbicides in water samples. Chemosphere 16:527-536.

Hamann, R., M. Meier and A. Kettrup. 1989. Determination of phenoxy acid herbicides by high-performance liquid chromatography and online enrichment, I . Possibilities of chromatographic seperation by means of high-performance liquid chromatography considering especially on-line enrichment of the herbicide compounds. Z. Anal. Chem. 334:231-234.

Hoke, S. H., E. E. Brueggemann, L. J. Baxter and T. Trybus. 1986. Determination of phenoxy acid herbicides using solid-phase extraction and high-performance liquid chromatography. J. of chromatography 357:429-432.

Meier, M., R. Hamann and A. Kettrup. 1989. Determination of phenoxy acid herbicides by high-performance liquid chromatography and on-line enrichment, II. Determination of phenoxy acid herbicides in soil sample. Z. Anal. Chem. 334:235-237.

Stevens T. S., and R. B. Ground. 1979. High pressure liquid chromatography of ester and salt formulation of 2-methyl-4-chlorophenoxyacetic acid. J. Assoc. Off. Anal. Chem. 62(4):738741.

Wolfgang S. und T. Monika 1981. Gaschromatographische bestimmung von rückstanden an pflanzenbehandlungsmitteln nach clean-up über gel-chromatographie und mini-kieselgelsäulen-chromatographie, 4. Gas-chromatographische bestimmung von 11 herbiciden phenoxyalkancarbonsäuren und ihren estern in pflanzenmaterial. Z. Anal Chem. 307:257-264. 